\section{MILITARY SPENDING AND ARMS PROCUREMENT IN THE GULF STATES}

\author{
CARINA SOLMIRANO AND PIETER D. WEZEMAN
}

Recent increases in military spending and arms procurement by the eight states bordering the Gulf-Bahrain, Iran, Iraq, Kuwait, Oman, Qatar, Saudi Arabia and the United Arab Emirates (UAE)-have revived widespread discussion about the possible impacts of military build-ups in the region. Saudi Arabia and the UAE stand out for their high levels of spending and arms imports, yet almost all the Gulf states devote a larger share of their gross domestic product (GDP) to military spending than the global average.

Assessments of military developments in the Gulf states are complicated by very low levels of public transparency. This fact sheet aims to inform debate on the economic burden of military spending and on arms procurements in the Gulf states. It brings together SIPRI data on the Gulf states' military expenditure and on arms transfers to the region, taken from the SIPRI Military Expenditure Database and the SIPRI Arms Transfers Database. ${ }^{1}$

\section{MILITARY EXPENDITURE IN THE GULF STATES}

The available data on the Gulf states' military expenditure is highly uncertain. In many cases - notably Bahrain and Iran-not all military expenditure appears in the official figures; while in others-notably Oman, Qatar and Saudi Arabia-states do not report their military spending separately from their broader spending on security (including internal security). It is also unclear whether some arms imports are paid for directly from oil revenues and thus do not appear in government accounts. In the case of Iraq, only budget figures are available, and actual expenditure may vary significantly.

The patchiness of the data makes it hard to describe regional trends in military spending. However, Saudi Arabia is clearly the biggest spender, followed by the UAE and Iran (see table 1). Iraq's military budget shrank by almost 30 per cent between 2008 and 2009. Almost all the Gulf states consistently spend a greater share of their GDP on the military than the global average (see table 2). Indeed, in the period 2000-2008, Oman and Saudi Arabia spent more of their GDP on the military than any other country for which data is available.

${ }^{1}$ SIPRI Military Expenditure Database <http://www.sipri.org/databases/milex>; and SIPRI Arms Transfers Database, <http://www.sipri.org/databases/armstransfers $>$. These databases are based on open-source data. They also provide further relevant details about military expenditure and arms procurement in the Gulf and the wider Middle East region, as well as full information about the data sources and methodologies used.

\section{KEY FACTS}

- Saudi Arabia is the biggest military spender in the Gulf, followed by the UAE and Iran.

- Almost all the Gulf states consistently spend a greater share of their GDP on the military than the global average.

- The UAE accounted for 57 per cent of the volume of imports of major conventional weapons in the period 2005-2009 and Saudi Arabia for 10 per cent.

- In the period 1990-2009, Saudi Arabia was the largest arms importer in the Gulf.

- The volume of arms imported by the UAE has increased significantly over the past decade and the country is likely to remain a major arms importer in the coming years.

- Signed contracts and known procurement plans indicate that Saudi Arabian arms imports are set to increase significantly.

- Iraq is rebuilding its armed forces from scratch and has plans to buy a wide range of major conventional weapons from a variety of countries.

- Iran's arms purchases have been relatively small in recent years. In 2010 it was placed under a wide-ranging $\mathrm{UN}$ arms embargo. 
Table 1. Military expenditure of the Gulf states, 2000-2009

Figures in the last column (marked *) are in current US\$ m. for 2009. All other figures are in US\$ m. at constant (2008) prices and exchange rates. Figures are for calendar years.

\begin{tabular}{|c|c|c|c|c|c|c|c|c|c|c|c|}
\hline Country & 2000 & 2001 & 2002 & 2003 & 2004 & 2005 & 2006 & 2007 & 2008 & 2009 & $2009 *$ \\
\hline Bahrain & 368 & 387 & 462 & 531 & 535 & 529 & 576 & 609 & 651 & {$[721]$} & [742] \\
\hline Iran & 7409 & 8175 & 6148 & 7195 & 9109 & 11296 & 12233 & 10158 & 9174 & .. & .. \\
\hline Iraq & . & . & . & . & . & $(2845)$ & (2 383) & (2 097) & (5 324) & (3 814) & (4 156) \\
\hline Kuwait & 4023 & 3954 & 4080 & 4396 & 4732 & 4580 & 4550 & 5109 & 4660 & 4589 & 4485 \\
\hline Oman & 2621 & 3049 & 3140 & 3303 & 3713 & 4476 & 4786 & 4849 & 4617 & 4003 & 4018 \\
\hline Qatar & . & . & 1588 & 1602 & 1476 & 1569 & 1657 & 2020 & . & . & . \\
\hline Saudi Arabia & 23523 & 25053 & 21995 & 22157 & 24632 & 29680 & 33809 & 38946 & 38223 & 39257 & 41273 \\
\hline UAE & [10 940] & {$\left[\begin{array}{ll}10 & 575\end{array}\right]$} & {$\left[\begin{array}{ll}9 & 725]\end{array}\right.$} & {$\left[\begin{array}{ll}10 & 201\end{array}\right]$} & {$\left[\begin{array}{ll}11 & 016\end{array}\right]$} & [10 254] & [12 098] & {$\left[\begin{array}{ll}13 & 052\end{array}\right]$} & . & . & .. \\
\hline
\end{tabular}

.. = data not available; ()$=$ uncertain figure; [] = SIPRI estimate.

Source: SIPRI Military Expenditure Database, <http://www.sipri.org/databases/milex/>.

\section{ARMS TRANSFERS TO THE GULF STATES}

The Gulf states accounted for 10 per cent of imports of major conventional weapons in the period 2005-2009. Since arms production capabilities in the region are limited, almost all procurements of major weapons were imports.

The weapons were supplied by at least 30 countries (see table 3). The largest suppliers were the United States, France, Russia, the United Kingdom and China. Russian and Chinese exports went mainly to Iran, which received no major arms from the USA or from most European states.

Figure 1 shows how the pattern of imports to the region has changed over time. While the UAE accounted for 57 percent of thevolume of imports ofmajor conventional weapons over the period 2005-2009 and Saudi Arabia for only 10 per cent, over the longer period 1990-2009 Saudi Arabia was the largest importer in the Gulf region. The most significant transfers of major conventional weapons to the Gulf states since 2005 are detailed below, along with reported arms procurement plans. Details of these and all other transfers are available in the SIPRI Arms Transfers Database.

Reports about arms procurement plans in the Gulf states must be treated

Table 2. Military expenditure by the Gulf states, as a percentage of gross domestic product, 2000-2008

\begin{tabular}{lccccccccc}
\hline Country & 2000 & 2001 & 2002 & 2003 & 2004 & 2005 & 2006 & 2007 & 2008 \\
\hline Bahrain & 4.0 & 4.2 & 4.7 & 4.8 & 4.3 & 3.6 & 3.4 & 3.2 & 3.0 \\
Iran & 3.8 & 4.0 & 2.5 & 2.9 & 3.3 & 3.8 & 3.8 & 2.9 & 2.7 \\
Iraq & $\ldots$ & $\ldots$ & $\ldots$ & $\ldots$ & $(1.9)$ & $(2.6)$ & $(2.7)$ & $(2.9)$ & $(5.4)$ \\
Kuwait & 7.2 & 7.7 & 7.4 & 6.5 & 5.8 & 4.3 & 3.6 & 3.8 & 3.2 \\
Oman & 10.8 & 12.5 & 12.4 & 12.2 & 12.1 & 11.8 & 11.0 & 10.4 & 7.7 \\
Qatar & $\ldots$ & $\ldots$ & 4.7 & 4.0 & 2.9 & 2.5 & 2.2 & 2.5 & $\ldots$ \\
Saudi Arabia & 10.6 & 11.5 & 9.8 & 8.7 & 8.4 & 8.0 & 8.3 & 9.2 & 8.2 \\
UAE & {$[9.4]$} & {$[9.8]$} & {$[8.6]$} & {$[7.9]$} & {$[7.4]$} & {$[5.6]$} & {$[5.9]$} & {$[5.9]$} & $\ldots$ \\
World total & 2.3 & 2.3 & 2.4 & 2.5 & 2.5 & 2.5 & 2.4 & 2.4 & 2.4 \\
\hline
\end{tabular}

.. = data not available; ()$=$ uncertain figure; [] = SIPRI estimate.

Source: SIPRI Military Expenditure Database, <http://www.sipri.org/databases/milex/>. with caution. Until a contract is signed, it is uncertain how many items will be bought, when and from whom.

\section{The United Arab Emirates}

The volume of arms imported by the UAE has increased significantly in the past decade and the country is likely to remain a major arms importer in the coming years. Contracts for the delivery of 62 Mirage2000-9 combat aircraft from France and 80 F-16E combat 
aircraft from the USA were completed in 2005-2008. In 2008-2009, $30 \mathrm{AH}-64 \mathrm{D}$ combat helicopters were delivered from the USA.

Contractsbeingimplemented include the delivery from the USA of 4 Patriot surface-toair missile (SAM) systems, 60 UH-60M armed transport helicopters, and $12 \mathrm{C}-130 \mathrm{~J}-30$ and $6 \mathrm{C}-17$ transport aircraft; from France of 3 A-330 MRTT tanker/transport aircraft and 6 Baynunah corvettes; from Russia of up to 50 Pantsyr-S1 air defence systems; and from Italy of 2 Falaj-2 corvettes and 1 Abu Dhabi frigate.

The UAE's arms procurement plans include 3 Terminal High Altitude Area Defence (THAAD) anti-ballistic missile systems and $16 \mathrm{CH}-47 \mathrm{~F}$ transport helicopters from the USA; 60 combat aircraft from France or the USA; 48 M-346 advanced trainer aircraft and another 2 Falaj-2 corvettes and 1 Abu Dhabi frigate from Italy; and 3 airborne early warning aircraft, which several countries are competing to supply.

\section{Saudi Arabia}

The volume of major arms imported by Saudi Arabia has been relatively low in the past decade compared with its imports in the 1990s. However, signed contracts and known procurement plans indicate that Saudi Arabia's arms imports are set to increase significantly once again.

Contracts being implemented include the delivery of 72 Typhoon combat aircraft and probably Storm Shadow long-range air-to-surface missiles from the UK, as part of a major upgrade of Tornado combat aircraft; $12 \mathrm{AH}-64 \mathrm{D}$ combat helicopters, $35 \mathrm{UH}-60 \mathrm{~L}$ transport helicopters, about $373 \mathrm{M}-1 \mathrm{~A} 2 \mathrm{~S}$ tanks, and new engines to upgrade $70 \mathrm{~F}-15 \mathrm{~S}$ combat aircraft from the USA; 724 Piranha/LAV armoured personnel carriers (APCs) from Canada; and 6 A-330 MRTT tanker/transport aircraft from France. states, 1990-2009 and 2005-2009
Table 3. The suppliers of major conventional weapons to the Gulf states, 2005-2009

Figures are suppliers' percentage shares of each recipient's total volume of imports.

\begin{tabular}{|c|c|c|c|c|c|c|c|}
\hline \multirow[b]{2}{*}{ Recipient } & \multicolumn{7}{|c|}{ Supplier } \\
\hline & China & France & Russia & UK & USA & Others & Total \\
\hline Bahrain & - & - & - & 34 & 55 & 11 & 100 \\
\hline Iran & 35 & - & 65 & - & - & - & 100 \\
\hline Iraq & - & - & 14 & 1 & 52 & 33 & 100 \\
\hline Kuwait & - & 3 & - & - & 91 & 6 & 100 \\
\hline Oman & - & 15 & - & 4 & 79 & 2 & 100 \\
\hline Qatar & - & - & - & - & 98 & 2 & 100 \\
\hline Saudi Arabia & 6 & 4 & - & 42 & 40 & 8 & 100 \\
\hline UAE & - & 35 & 2 & - & 60 & 3 & 100 \\
\hline Gulf region & 4 & 21 & 9 & 5 & 54 & 7 & 100 \\
\hline
\end{tabular}

$-=$ nil.

Source: SIPRI Arms Transfers Database, <http://www.sipri.org/databases/armstransfers/>.

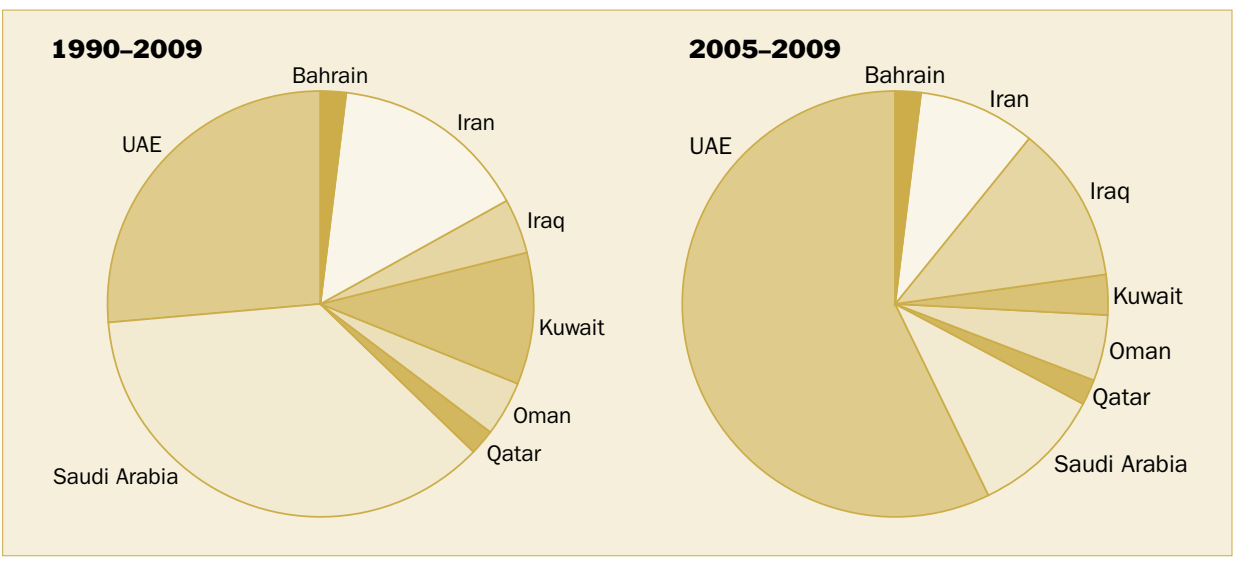

Figure 1. Relative volumes of imports of major conventional arms by the Gulf

The pie charts show the volume of imports by individual Gulf states as a share of the total volume of imports to the region.

Source: SIPRI Arms Transfers Database, <http://www.sipri.org/databases/armstransfers/>. 
SIPRI is an independent international institute dedicated to research into conflict, armaments, arms control and disarmament. Established in 1966, SIPRI provides data, analysis and recommendations, based on open sources, to policymakers, researchers, media and the interested public.

\section{GOVERNING BOARD}

Göran Lennmarker, Chairman (Sweden)

Dr Dewi Fortuna Anwar (Indonesia)

Dr Alexei G. Arbatov (Russia)

Ambassador Lakhdar Brahimi (Algeria)

Jayantha Dhanapala

(Sri Lanka)

Dr Nabil Elaraby (Egypt)

Ambassador Wolfgang

Ischinger (Germany)

Professor Mary Kaldor

(United Kingdom)

The Director

\section{DIRECTOR}

Dr Bates Gill (United States)

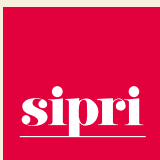

STOCKHOLM INTERNATIONAL PEACE RESEARCH INSTITUTE

Signalistgatan 9

SE-169 70 Solna, Sweden

Telephone: +4686559700

Fax: +4686559733

Email:sipri@sipri.org

Internet: www.sipri.org
Over the past few years there have been many reports of plans for large arms-acquisition programmes. These include $84 \mathrm{~F}-15 \mathrm{~S}$ combat aircraft, $72 \mathrm{UH}-60$ transport helicopters, $70 \mathrm{AH}-64 \mathrm{D}$ combat helicopters and $6 \mathrm{P}-8 \mathrm{~A}$ maritime patrol aircraft from the USA; 40 more Typhoon combat aircraft from the UK; 150 T-90S tanks, 250 BMP-3 armoured vehicles, and short- and long-range SAMs from Russia; and 4 frigates, which several countries are competing to supply.

\section{Oman}

Oman received $12 \mathrm{~F}-16 \mathrm{C}$ combat aircraft from the USA in 2005-2008. A contract for the delivery of 3 frigates from the UK is being implemented. Procurement plans include 18 F-16Ds from the USA and 24 Typhoon combat aircraft from the UK.

\section{Kuwait}

Kuwait received 16 AH-64D combat helicopters from the USA in 2007. Procurement plans include AC-3 or PAC-2 GEM-T missiles from the USA to upgrade Kuwait's Patriot SAM systems and between 14 and 28 combat aircraft, with French and USA producers competing for the order.

\section{Iraq}

Iraq received more than 11000 light APCs from various countries-primarily the USA-in the period 2005-2009. Contracts being implemented include the delivery of $140 \mathrm{M}-1 \mathrm{Al}$ tanks, 24 Bell-407 armed helicopters and $6 \mathrm{C}-130 \mathrm{~J}$ transport aircraft from the USA; over 400 BTR-4 APCs from Ukraine; 24 armed EC-135 helicopters from a French-German company; and $22 \mathrm{Mi}-17$ helicopters from Russia.

Iraq is rebuilding its armed forces from scratch and has plans to buy a wide range of major conventional weapons from a variety of countries. This includes the procurement of a first batch of $18 \mathrm{~F}-16 \mathrm{C}$ combat aircraft, 140 more M-1A1 tanks and over 1000 M-113A3 APCs from the USA; an unknown quantity of tanks from Ukraine; and 18-36 advanced trainer or light combat aircraft, offered by several suppliers.

\section{Iran}

Iran's most important recent arms import was the delivery of about 29 Tor-M1 (SA-15) medium-range SAM systems from Russia in 2006-2007. In June 2010 the United Nations Security Council imposed an embargo on the delivery of most major conventional weapons to Iran. Russia announced in late September 2010 that, as part of its implementation of the UN embargo, it had stopped the delivery of 5 S-300PMU-1 (SA-20A) SAM systems that Iran had ordered in 2007. 